\title{
Measurement of Steel Structure Elements in the Specialized Module of the IMAGE-SP Image Processing Software
}

\author{
A.G. Anisovich \\ The Physical-Technical Institute of the National Academy of Sciences of Belarus, \\ Kuprevich str., 10, Minsk 220141, Belarus
}

Received 01.10.2020

Accepted for publication 26.11.2020

\begin{abstract}
Grain size is one of the most important characteristics of the microstructure of metals and alloys. Determination of the grain size of steel is regulated by Standart 5639-82 "Steels and alloys. Methods for detection and determination of the grain size". Standart includes determining the grain score by comparison with reference scales, as well as manual measurement methods. The use of image processing software opens up new opportunities for the materials analysis, including for the quantitative metallographic analysis of steels and alloys. The purpose of this work was to test the specialized "Metallography" module to determine the grain score of the image processing software "IMAGE-SP", as well as to check the reliability of the obtained results using the example of ferritic and austenitic steels.

In the "Metallography" module, the analysis of standard images of annex No. 3 of Standart 5639-82, as well as real images of the structures of ferritic and austenitic steel, is carried out. It is shown that the results correspond to the definition of the Standart grain score. The divergence in the results is 1 point, which is acceptable.

The active development of software products for the quantitative analysis of images in metallography will make it possible to legitimize the methods of computer measurement of parameters of the structures of metals and alloys by creating appropriate standards. Successful testing of the specialized "Metallography" module demonstrates opportunities and prospects for further development of specialized software products for measuring quantitative values of metal and alloy structures. The active development of software for quantitative analysis of the images in metallography will make it possible to legalize methods for measuring parameters of metal and alloy structures by computer techniques.
\end{abstract}

Keywords: grain size, image processing software.

DOI: $10.21122 / 2220-9506-2020-11-4-279-288$

\begin{tabular}{ll}
\hline Адрес для переписки: & Address for correspondence: \\
А.Г. Анисович & A.G. Anisovich \\
Физико-технический институт Национальной & The Physical-Technical Institute of the National Academy \\
академии наук Беларуси, & of Sciences of Belarus, \\
ул. Купревича, 10, г. Минск 220141, Беларусь & Kuprevich str., 10, Minsk 220141, Belarus \\
e-таil: аппа-апіsоvich@yandex.ru & e-mail: anna-anisovich@yandex.ru \\
\hline Для цитирования: & For citation: \\
A.G. Anisovich. & A.G. Anisovich. \\
Measurement of Steel Structure Elements in the Specialized & Measurement of Steel Structure Elements in the Specialized \\
Module of the IMAGE-SP Image Processing Software. & Module of the IMAGE-SP Image Processing Software. \\
Приборы и методы измерений. & Devices and Methods of Measurements. \\
2020. - Т. 11, № 4.- - С. 279-288. & 2020, vol. 11, no. 4, pp. 279-288. \\
DОI: $10.21122 / 2220-9506-2020-11-4-279-288$ & DOI: 10.21122/2220-9506-2020-11-4-279-288 \\
\hline
\end{tabular}




\title{
Измерение элементов структуры стали \\ в специализированном модуле программы обработки изображений «IMAGE-SP»
}

\author{
А.Г. Анисович \\ Физико-технический институт Национальной академии наук Беларуси, \\ ул. Купревича, 10, г. Минск 220141, Беларусь \\ Поступила 01.10.2020 \\ Принята к печати 26.11.2020
}

Размер зерна является одной из наиболее важных характеристик микроструктуры металлов и сплавов. Определение размера зерна стали регламентируется ГОСТ 5639-82 «Стали и сплавы. Методы выявления и определения величины зерна» и включает определение балла зерна сравнением с эталонными шкалами, а также ручные способы измерений. Применение программ обработки изображений открывает новые возможности для анализа материалов, в том числе для количественного металлографического анализа сталей и сплавов. Целью данной работы являлось тестирование специализированного модуля «Металлография» по определению балла зерна программы обработки изображений «IMAGE - SP», а также проверка достоверности получаемых результатов на примере ферритных и аустенитных сталей.

В модуле «Металлография» проведён анализ стандартных изображений приложения № 3 ГОСТ 5639-82, а также реальных изображений структур ферритной и аустенитной стали. Показано, что результаты соответствуют определению балла зерна по ГОСТу. Расхождение в результатах составляет 1 балл, что является допустимым.

Успешное тестирование специализированного модуля «Металлография» демонстрирует возможности и перспективность дальнейшей разработки специализированных программных продуктов для измерения количественных показателей структуры металлов и сплавов. Активная разработка программных продуктов для количественного анализа изображений в металлографии позволит узаконить методы компьютерного измерения параметров структур металлов и сплавов путём создания соответствующих стандартов.

Ключевые слова: размер зерна, программы обработки изображений.

DOI: $10.21122 / 2220-9506-2020-11-4-279-288$

\begin{tabular}{ll}
\hline Адрес для переписки: & $\begin{array}{l}\text { Address for correspondence: } \\
\text { A.Г. Анисович }\end{array}$ \\
Физико-технический институт Национальной & The Physical-Technical Institute of the National Academy \\
академии наук Беларуси, & of Sciences of Belarus, \\
ул. Купревича, 10, г. Минск 220141, Беларусь & Kuprevich str., 10, Minsk 220141, Belarus \\
e-таil: аппа-апіsovich@yandex.ru & e-mail: anna-anisovich@yandex.ru \\
\hline Для цитирования: & For citation: \\
A.G. Anisovich. & A.G. Anisovich. \\
Measurement of Steel Structure Elements in the Specialized & Measurement of Steel Structure Elements in the Specialized \\
Module of the IMAGE-SP Image Processing Software. & Module of the IMAGE-SP Image Processing Software. \\
Приборы и методы измерений. & Devices and Methods of Measurements. \\
2020. - Т. 11, № 4.- С. 279-288. & 2020, vol. 11, no. 4, pp. 279-288. \\
DОI: 10.21122/2220-9506-2020-11-4-279-288 & DOI: 10.21122/2220-9506-2020-11-4-279-288 \\
\hline
\end{tabular}




\section{Introduction}

Nowadays the computer analysis of metal and alloy structures is widely used in the practice of research and industrial laboratories [1-3]. The application of image processing software opens up new opportunities for material analysis, and also for quantitative metallographic analysis of steels and alloys. In the previous years, it was impossible or difficult to make some measurements because of their high labour intensity. Such measurements include the determination of quantitative parameters of grains and metal alloy phases by a stereometric metallography method. It implies the measurement of areas and linear dimensions of the structural components.

The grain size is one of the most important characteristics of metal and alloy microstructures. In particular, the yield stress $\sigma$-grain size $d$ dependence is described by the famous Hall-Petch relation that connects the grain size and physical and mechanical metal characteristics [4]:

$$
\sigma=\sigma_{0}+k d^{-\frac{1}{2}}
$$

where $\sigma_{0}-$ slip resistance limit of the grain body; $k-$ the strengthening coefficient.

The strengthening at cold plastic deformation is connected with the interaction of dislocations with each other and with large-angle boundaries of grains. The more developed grain-boundary surface, i. e. the finer the grain, the stronger the interaction and metal or alloy. The increase of the failure load at mechanical tests and increase of the fatigue limit, ultimate tensile strength and physical properties are connected with grain dispersion [5].

The grain size measurement in steel is regulated by Standart 5639-82 "Steels and alloys. Methods for detection and determination of the grain size". The standard defines grains of metals as separate crystals of a polycrystalline conglomerate separated by adjacent surfaces which are called grain boundaries. The grain size is an average value of the grain random sections in the plane of a metallographic specimen. In accordance with Standart 5639-82, it is determined by the following methods:

1. Visual comparison of the grains visible under the microscope with scale standards given in the mandatory annex, with a certain grain number (score); scales 1 and 2 are used to estimate the grain size in all steels and alloys, scale 3 is for austenitic steels where twins have been revealed after etching.
2. Calculation of the grain number per unit of the specimen surface with the measurement of the average diameter and average area of the grain.

3. Calculation of the grain boundary intersections by the straight-line segments with the measurement of the average nominal diameter in case of equiaxed grains; the number of grains in $1 \mathrm{~mm}^{2}$ in case of nonequiaxed grains.

4. The measurement of the chord length under the microscope or with the use of photomicrographs with determining relative proportion of the grains of the certain size.

Methods 2-4 refer to manual measuring methods.

Modern metallographic equipment allows to make an automated analysis of the grain structure. The Belarusian market presents such image-processing software as Video-TesT, Autoscan, SIAMS, and also foreign software programs that offer methods of quantitative experimental data processing. The SIAMS software is a the only certified program on the Russian market that offers the measurement of quantitative parameters of metal and alloy structures in accordance with operating standards.

The Belarusian-made "IMAGE-SP" software is one of the youngest metallography programs on the Belarusian market; the manufacturing company is "SYSPROG". The use of the image-processing software for measuring and estimating parameters of metal and alloy structures, although it is unconditional for a scientific community, is not legally permitted at the level of standards [6]. In the practice of regulated laboratories, the research reports are issued strictly in accordance with standard methods, described in Standarts. Therefore, it is necessary to develop special software programs where the measurement would be taken according to operating standards. The "Metallography" ${ }^{1}$ module for measuring the grain score has been created in the program "IMAGE-SP" according to the method of Standart 5639-82.

The final mandatory step in the development of any software program is its testing. At the testing stage, system errors of the software are revealed as well as the verification of obtained results is carried out.

The purpose of the work was a testing of the specialized "Metallography" module to determine the grain score of the image-processing software

${ }^{1}$ The "Metallography" module is created by the manufacturing company "SYSPROG" with direct involvement of the Physical-Technical Institute of the National Academy of Sciences of Belarus 
"IMAGE - SP" as well as the verification of obtained results using the example of ferritic and austenitic steels.

\section{Materials and experimental techniques}

The images of scales No. 1, 2, 3 in accordance with Standart 5639-82 "Steels and alloys. Methods for detection and determination of the grain size" and the images of steel microstructures with ferritic and austenitic structures have been selected as objects of research.

A metallographic complex based on the metallographic inverted-stage microscope MI-1 has been used for photographing and quantitative processing. The image fixation has been carried out using a video camera with an output to a computer monitor and its further processing using "IMAGE-SP" program. The program is designed to acquire images using electron microscopes and cameras as well as to subsequent processing of obtained images. An important feature of the "IMAGE - SP" program is a possibility to work with high-resolution images. The program makes it possible to measure the following parameters of the grain structure: area, minimum and maximum diameters, the length, the width and average grain size, perimeter, equivalent diameter as well as some other parameters at their increase.

The program calibration and creation of the calibration table of increments have been carried out using a certified object micrometer (Standart 751355) [7].

The example of the computer processing structure of the scale 3 of Standart 5639-82 is presented in Figure 1 that contains the initial structure, "mask", obtained as a result of the image processing without twins, and "mask" obtained as a result of the image processing with twins. By "without twins", it is implied that the twin (the lattice defect of the austenitic grain) is considered as a grain part. By "with twins", it is implied that the twin is considered as a separate grain in the microstructure. The mask is a result of implementing the operation "Object detection" where the objects, subject to a quantitative analysis, are highlighted in a certain color. The class coloring is carried out according to the sizes of image objects. It is designed for a visual image of the grain size relative to each other. In this case, grains relating to this range of the grain size values, are highlighted in one color.

Figures 2-4 presents the window of the "Metallography" module at step-by-step mea- surement of the grain score. Figure 2 shows the first step - the site selection for analysis. The program offers various options for analysis equal in area of $0.5 \mathrm{~mm}^{2}$ according to the requirements of Standart 5639-82.
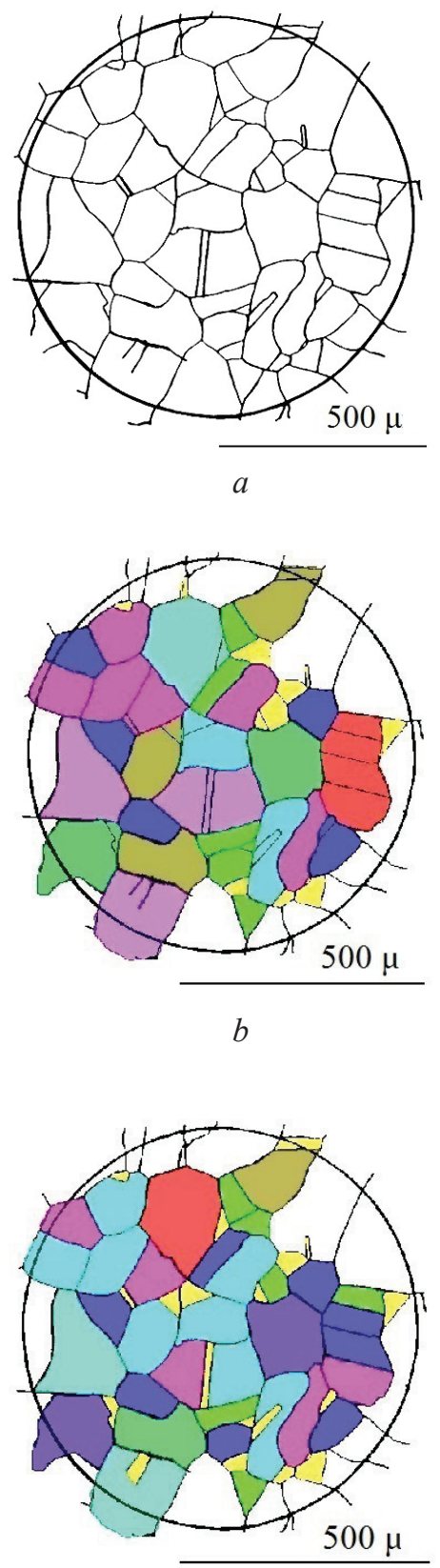

$c$

Figure 1 - The image masks of scale 3 according to Standart 5639-82: $a$-initial structure; $b$ - without twins; $c$ - with twins

After selecting a site of the structure, the objects are detected, distributed into size classes and edited (Figure 3). At the final stage, the grain score is determined, and average structure characteristics are mea- 
sured in accordance with Standart (Figure 4). Also, the measurement and calculation results for each grain (area, lateral and longitudinal sizes, equivalent diameter, form factor, etc.) are printed on the screen.

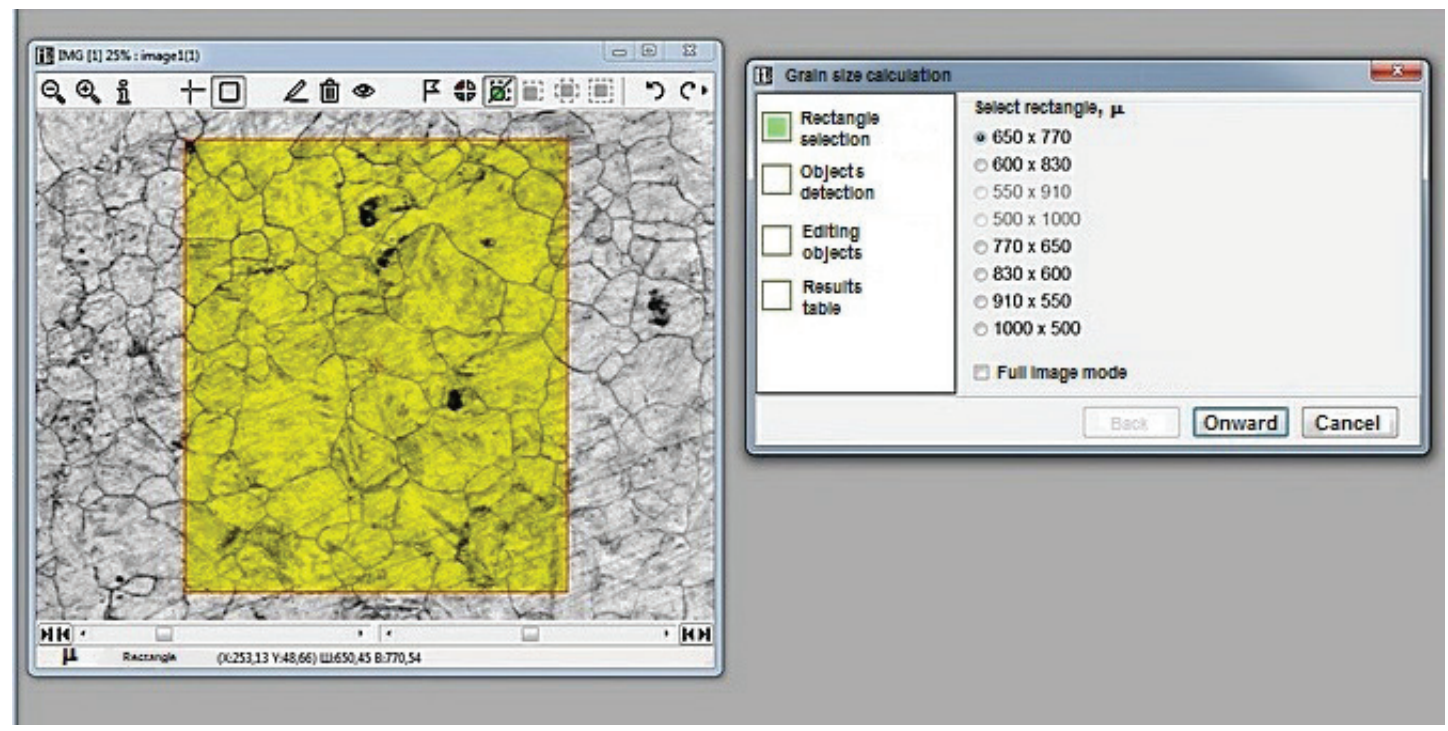

Figure 2 - The window of the "Metallography" module: selection of a site for structure analysis

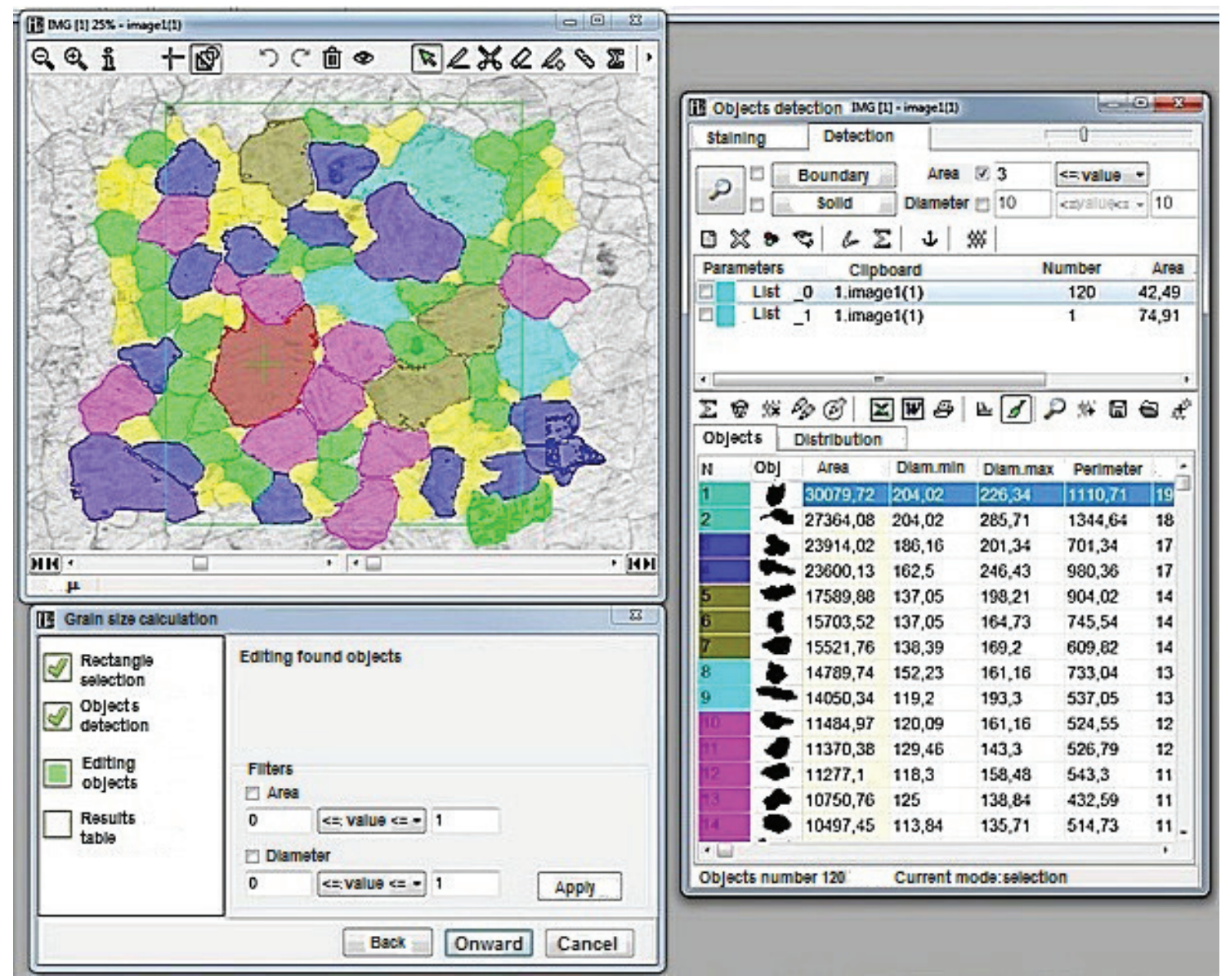

Figure 3 - The window of the "Metallography" module: the distribution of the objects by size classes and their editing 


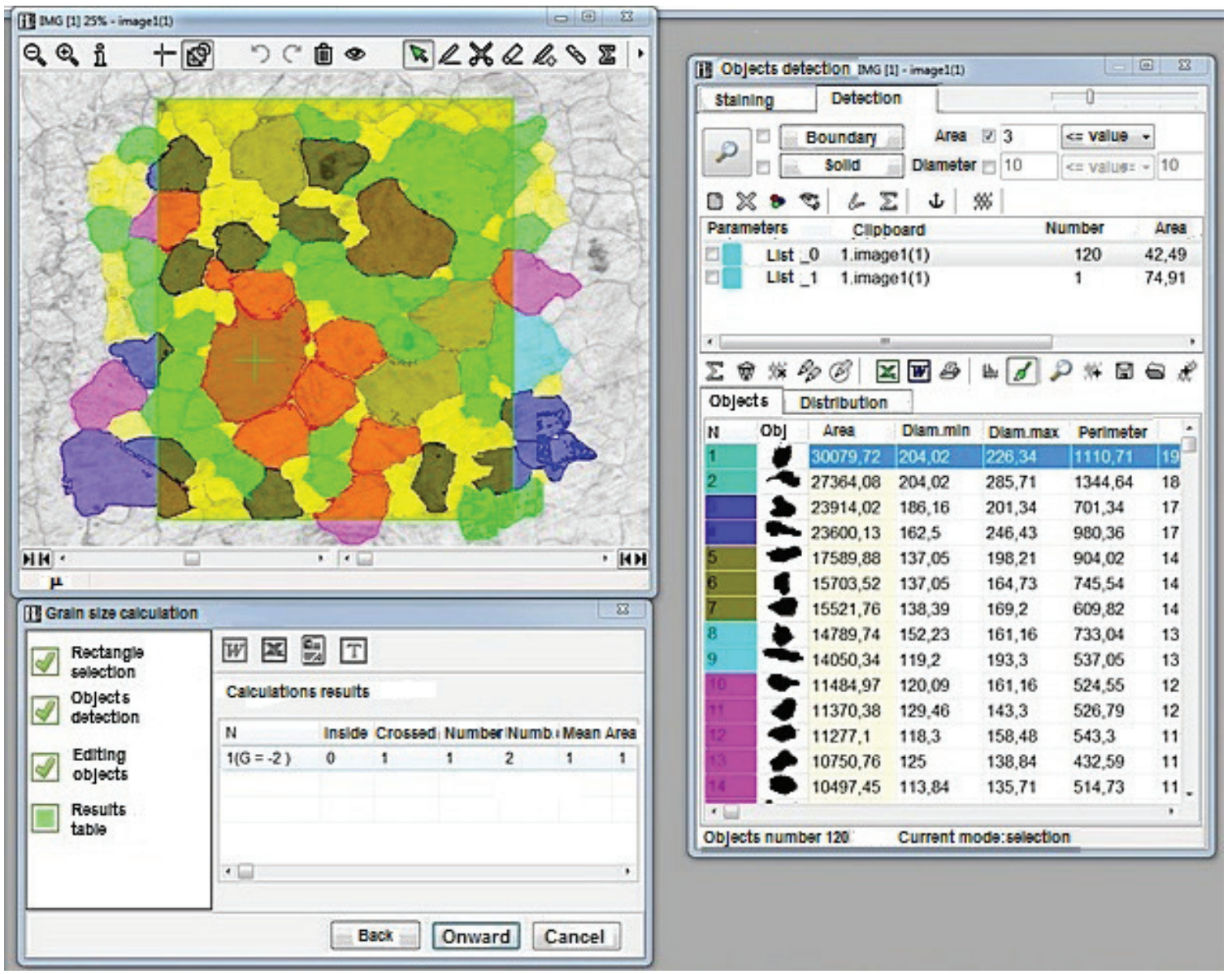

Figure 4 - The window of the "Metallography" module: the final stage - determining the grain score

\section{Results and their discussion}

The site with a relatively uniform structure has been selected for the quantitative analysis of the images of ferritic steel structure (Figure 5). The grains are highlighted in different colors in accordance with their sizes. The results obtained for three identical samples (Table 1) when determining the grain score in the "Metallography" module are presented below:

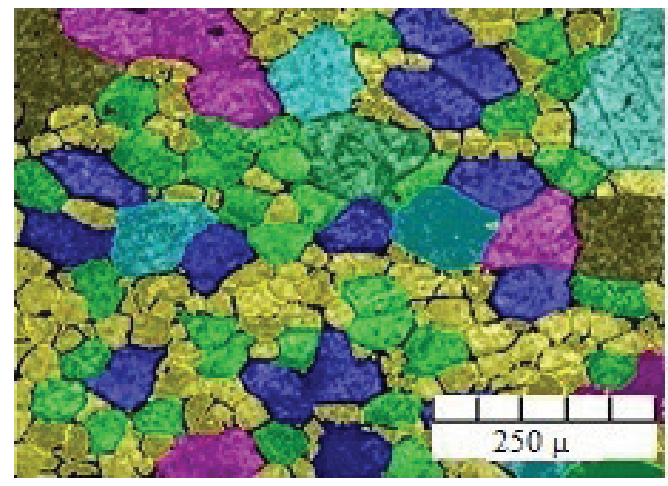

Figure 5 - Coloring of classes in the quantitative analysis of ferritic steel
According to the presented results, it is obvious that the grain of steel corresponds to score 6 . The histogram (Figure 6) shows the grain distribution of ferritic steel over their equivalent diameters. The equivalent diameter is a diameter measured from the grain area on the assumption that the grain is a circle. The maximum number of grains belongs to the class the value of which lies in the range of 50-100 $\mu$, which makes it possible to classify it as score 5-6 according to Standart.

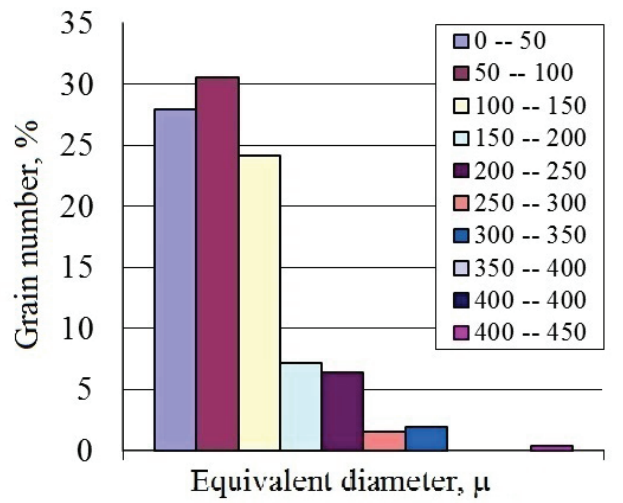

Figure 6-Distribution of ferritic steel grains over equivalent diameters 
Results of determining the grain score of ferritic steel

Table 1

\begin{tabular}{lccccccc}
\hline \multicolumn{7}{c}{ Grain number counting } \\
\hline $\begin{array}{l}\text { Sample } \\
\text { No. }\end{array}$ & $\begin{array}{c}\text { N grain } \\
\text { score }\end{array}$ & Inner* & Crossed** & $\begin{array}{c}\text { Grain } \\
\text { number in } \\
0.5 \mathrm{~mm}^{2}\end{array}$ & $\begin{array}{c}\text { Grain } \\
\text { number in } \\
1 \mathrm{~mm}^{2}\end{array}$ & $\begin{array}{c}\text { Average } \\
\text { area, } \mathrm{mm}^{2}\end{array}$ & $\begin{array}{c}\text { Average } \\
\text { diameter, } \\
\mathrm{mm}\end{array}$ \\
\hline 1 & $1(\mathrm{G}=6)$ & 241 & 24 & 252 & 504 & 0.00198 & 0.045 \\
2 & $1(\mathrm{G}=5)$ & 167 & 32 & 182 & 364 & 0.00275 & 0.052 \\
3 & $1(\mathrm{G}=6)$ & 350 & 30 & 364 & 728 & 0.00137 & 0.037 \\
\hline
\end{tabular}

* - the grain number in the site for analysis;

** - the grain number crossed by the site boundaries for analysis

In Standart 5639-82, the scale No. 3 is meant for determining the grain score of steel with twins. As a result of the twin formation, the grain is discontinuously divided into two parts by the twin plane, and the crystallographic plane of one part of the grain becomes a mirror image of the other part, lying on the other side of the twinning plane [8]. The straight line of the twins, visible in the structure, is a trace of the intersection of the boundary-twin plane with a thin section plane. There is a regular or coherent connection at the boundary between the arrangement of atoms in matrix and in the twin. Coherent boundaries of the twin have elastic energy which is far less than ordinary incoherent boundaries have. The misorientation of such boundaries is $\approx 10$ $20^{\circ}$ which makes it possible to classify them as largeangle boundaries. In Standart 5639-82, crystals with twins are considered as grains in the presence of twins.

Figure 7 contains the histograms of the grain distribution in areas for scale 3 of Standart (austenite grain score 3) with measuring in the "IMAGESP" program. The average area of the grain in a sample, where twins are not taken into account, is $0.009552 \mathrm{~mm}^{2}$ which corresponds to score 3 of Standart $\left(0.0156 \mathrm{~mm}^{2}\right)$. The average area of the grain in a sample where twins are taken into account, is $0.006466 \mathrm{~mm}^{2}$ which corresponds to score 4 of Standart $\left(0.00781 \mathrm{~mm}^{2}\right)$. The difference in the samples is 1 point of Standart 5639-82 that corresponds to the requirements of the standard.

Table 2 presents the values of the average area and diameter of the grain on scale 3 for structure standards with grain scores No. 1-10 without twins and with twins in the grain when determined in the "Metallography" module.

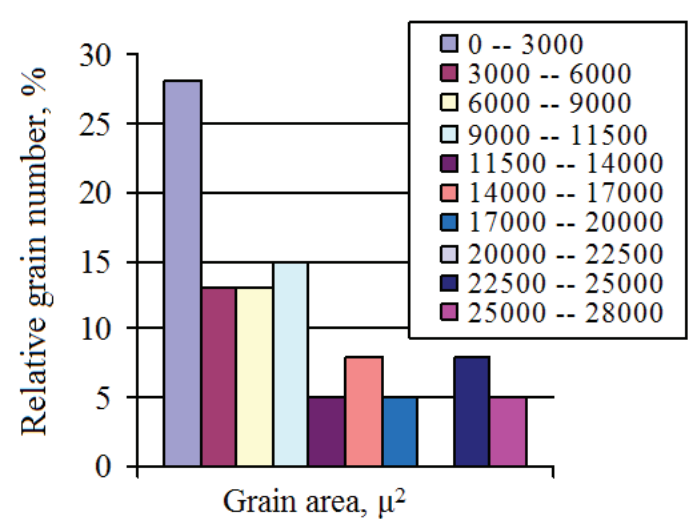

$a$

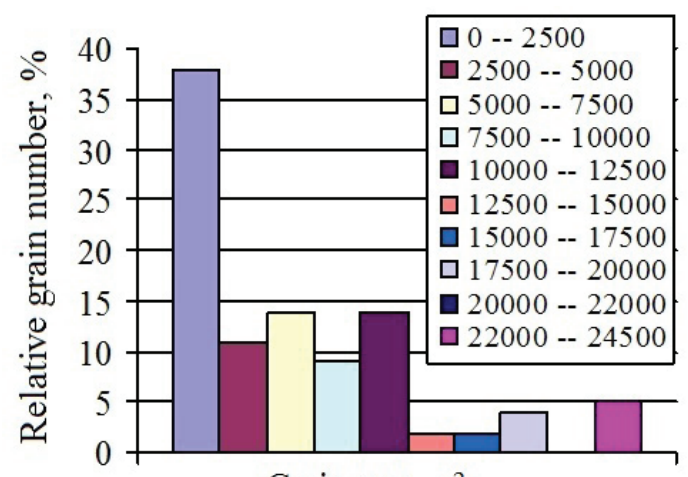

Grain area, $\mu^{2}$

$b$

Figure 7 - Histograms of the grain distribution in areas for the grain score No. 3: $a$-without twins; $b$-with twins

According to the presented results, it is obvious that there is no substantial difference in values with or without twins when estimating austenite structure working in the specialized module. The variation in values is 1 point that is within acceptable limits when determining the grain score of Standart 5639-82. 
Calculated values of the grain score and sizes on a scale 3 of Standart 5639-82

\begin{tabular}{|c|c|c|c|c|c|}
\hline \multicolumn{3}{|c|}{ Without twins } & \multicolumn{3}{|c|}{ With twins } \\
\hline Grain score & $\begin{array}{l}\text { Average grain } \\
\text { area, } \mathrm{mm}^{2}\end{array}$ & $d, \mathrm{~mm}$ & Grain score & $\begin{array}{l}\text { Average grain } \\
\text { area, } \mathrm{mm}^{2}\end{array}$ & $d, \mathrm{~mm}$ \\
\hline 2 & 0.0277 & 0.187 & 2 & 0.0319 & 0.202 \\
\hline 3 & 0.021518 & 0.166 & 3 & 0.011117 & 0.119 \\
\hline 4 & 0.009552 & 0.110 & 4 & 0.006466 & 0.09 \\
\hline 5 & 0.005001 & 0.08 & 5 & 0.002857 & 0.06 \\
\hline 6 & 0.002643 & 0.058 & 6 & 0.001973 & 0.5 \\
\hline 7 & 0.000959 & 0.035 & 7 & 0.000816 & 0.032 \\
\hline 8 & 0.000451 & 0.024 & 8 & 0.000400 & 0.023 \\
\hline 9 & 0.000268 & 0.018 & 9 & 0.000239 & 0.017 \\
\hline 10 & 0.000138 & 0.013 & 10 & 0.000129 & 0.012 \\
\hline 11 & 0.000067 & 0.009 & 11 & 0.000066 & 0.009 \\
\hline
\end{tabular}

The following images are presented below: the microstructure of austenitic steel (Figure $8 a$ ), the image mask when determining the grain size without twins (Figure $8 b$ ) and with twins (Figure 8c) when determining the grain score in the "Metallography" module. Table 3 shows the values of the average area and average diameter of the grain when determining in the "Metallography" module.

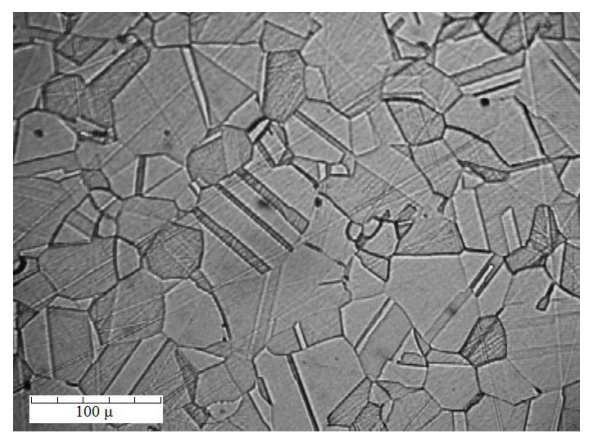

$a$

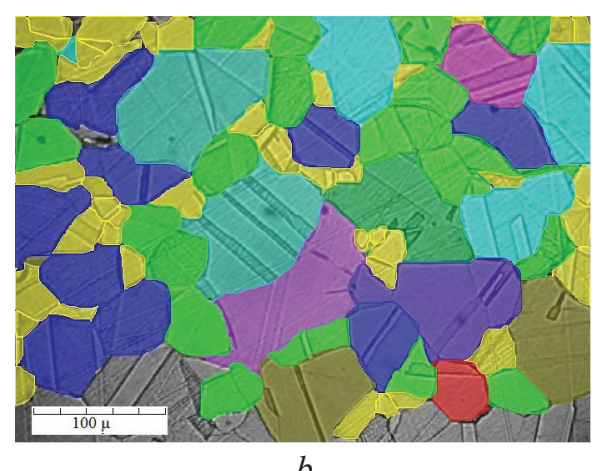

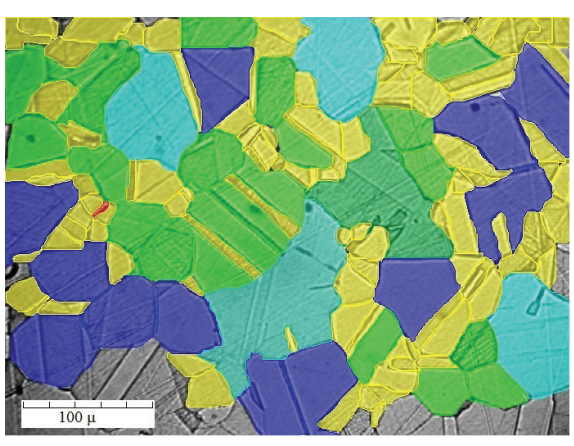

Figure 8 - The image processing result: $a$-the initial structure of austenitic steel; $b$ - without twins; $c$ - with twins

The values of the average grain area and the average grain diameter do not have a significant difference with each other, however, the grain score of austenitic steel does not change and has No. 7 of Standart 5639-82 both, with or without twins. Figure 9 shows the grain area of austenitic steel with and without twins. The distributions are not significantly different.

The estimation of the measurement error in the work of IMAGE-SP program is reviewed in [7]. The reasons for the error origin can be the following [9]: limited accuracy of manufacturing measurement tools; the effect on measurement of ambient conditions; operator's actions; approximate nature of 
regulations used for determining measurable values. In the quantitative analysis of the structure in the IMAGE-SP, the error is connected with the accuracy of measurement tools, and also with operator's error. The error for manual methods of structure processing is $3.3-8.1 \%$ at the confidence coefficient of $0.50-0.90$.

Table 3

Calculated values of the grain sizes of steel

\begin{tabular}{|c|c|c|c|c|c|}
\hline \multicolumn{3}{|c|}{ Without twins } & \multicolumn{3}{|c|}{ With twins } \\
\hline $\begin{array}{l}\text { Grain } \\
\text { score }\end{array}$ & $\begin{array}{c}\text { Average } \\
\text { grain } \\
\text { area, } \\
\mathrm{mm}^{2}\end{array}$ & $d, \mathrm{~mm}$ & $\begin{array}{l}\text { Grain } \\
\text { score }\end{array}$ & $\begin{array}{c}\text { Average } \\
\text { grain } \\
\text { area, } \\
\mathrm{mm}^{2}\end{array}$ & $d, \mathrm{~mm}$ \\
\hline 7 & 0.000949 & 0.032 & № 7 & 0.001498 & 0.038 \\
\hline
\end{tabular}

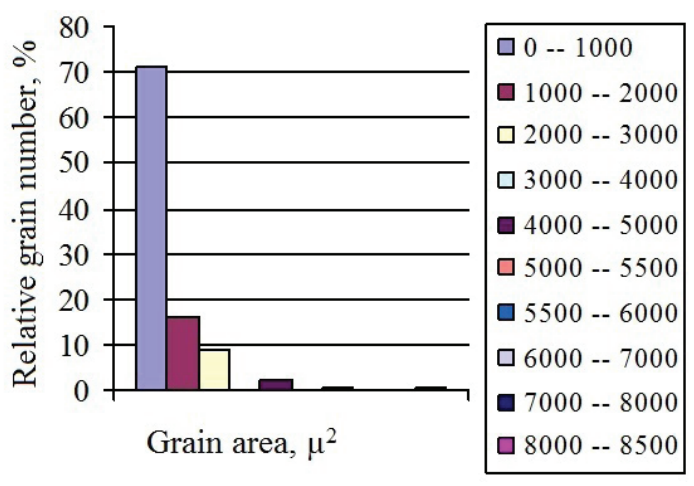

$a$

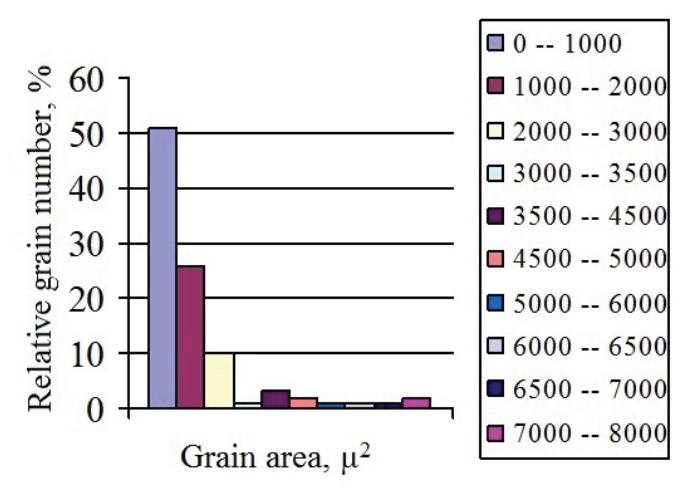

$b$

Figure 9-Histograms of the grain distribution for austenitic steel: $a$ - without twins; $b$ - with twins

When image processing by one operator, it is obtained that the average fractional error in measuring the grain size (according to the results of fivefold determination) is $0.9 \%$. Different operators' errors (when analyzing the same image) can be connected both with a difference in professional experience and with different structure vision. The average fractional error in measuring the grain size, determined by four operators' actions for the same image, is $6.0 \%$.

\section{Conclusion}

The new specialized "Metallography" module is created which allows to obtain high integrity results and can be used in the practice of specialized and regulated laboratories.

When determining the grain score in the "Metallography" module for the steel structure with an equiaxed grain, it is obtained that the results correspond to Standart; the discrepancy in the results is 1 point. When analyzing the standard scales 3 of Standart 5639-82, as well as the structure of austenitic steel, there is no significant difference in the values of the grain score, both with and without twins; the discrepancy in the results is 1 point.

Successful testing of the specialized "Metallography" module demonstrates opportunities and prospects for further development of specialized software products for measuring quantitative values of metal and alloy structures.

Active development of software products for quantitative analysis of the images in metallography allows to create corresponding standards for measuring parameters of metal and alloy structures by computer techniques.

\section{References}

1. Kazakov A.A., Kiselev D.V., Andreyeva S.V., Chigintsev L.S., Golovin S.V., Yegorov V.A., Markov S.I. [Development of a method for quantitative assessment of microstructural banding of low-alloy pipe steels using automatic image analysis]. Chernyye metally [Ferrous metals], 2007, no. 7, pp. 31-37 (in Russian).

2. Gonzalez R.C., Woods R.E. Digital image and processing. New York, Pearson Education, Inc., publishing as Prentice Holl., 2002, 1072 p.

3. Kazakov A.A., Chigintsev L.S., Kazakova Ye.I., Ryaboshuk S.V., Markov S.I. [Methodology for evaluating the liquation strip of sheet metal]. Chernyye metally [Ferrous metals], 2009, no. 12, pp. 17-22 (in Russian).

4. Carlton C.E., Ferreira P.J. What is behind the inverse Hall-Petch effect in nanocrystalline materials? Acta Materialia, 2007, vol. 55, pp. 3749-3756.

DOI: $10.1016 /$ j.actamat.2007.02.021

5. Ovchinnikov V.V. Metallovedeniye [Metallurgy]. Moscow, Forum, 2019, 320 p. 
6. Anisovich A.G., Rumyantseva I.N., Bisluk L.V. [Determination of steel grain grade by computer methods]. Lit'ye i metallurgiya [Foundry production and metallurgy], 2010, no. 3, pp. 100-104 (in Russian).

DOI: $10.21122 / 1683-6065-2010-3-100-104$

7. Anisovich A.G., Basalay A.V. [Assessment of mistakes of an operator at quantitative analysis of structure by computer methods]. Lit'ye $i$ metallurgiya [Foundry production and metallurgy], 2012, vol. 68, no. 4, pp. 145-150 (in Russian).

DOI: $10.21122 / 1683-6065-2012-4-145-150$

8. Gorelik S.S., Dobatkin S.V., Kaputkina L.M. Rekristallizatsiya metallov $i$ splavov [Recrystallization of metals and alloys]. Moscow, Moscow Institute of Steels and Alloys, 2005, 432 p.

9. Kozlov M.G. Metrologiya i standartizatsiya [Metrology and standardization]. S.-Pb.: Petersburg Press Institute, 2001, 372 p. 